\title{
MALIGNANT PRIAPISM AND SECONDARY BLADDER CANCER
}

Pablo Eguiluz Lumbreras, Alberto Palacios Hernandez, Oscar Heredero Zorzo, Florencio Cañada de Arriba, Javier Garcia Garcia, Victoriano Ramon Gomez Zancajo and Manuel Urrutia Avisrror

Department and Chair Urology. Salamanca Clinic Hospital. Salamanca. Spain.

Summary.- OBJECTIVE: We report a rare case of malignant priapism secondary to transitional cell carcinoma.

METHODS: The patient with bladder cancer (pT4G3) presented with painful penile erection. Corpora cavernosa biopsy was done.

RESULTS: The pathologic diagnosis was penile metasta-sis of transitional cell carcinoma.

CONCLUSIONS: Priapism secondary to penile metastasis of transitional cell carcinoma is rare and indicates advanced disease with a poor prognosis.

CORRESPONDENCE

Pablo Eguíluz Lumbreras

Henry Collet, 14-16, Portal: 5, 2C.

37007 Salamanca. (Spain).

paeglu@hotmail.com

Accepted for publication: March, $16^{\text {th }} 2008$. 
Keywords: Priapism malignant. Bladder cancer.

Resumen.- OBJETIVO: Presentamos un caso infrecuente de priapismo maligno secundario a carcinoma de celulas transicionales de la vejiga.

MÉTODOS: El paciente portador de un cancer vesical (pT4G3) presenta una tumefacción dolorosa peneana. Realizamos biopsia de los cuerpos cavernosos.

RESULTADOS: El informe de la anatomía patológica muestra metástasis peneana de carcinoma de células de transición.

CONCLUSIONES: El priapismo secundario a metástasis peniana por carcinoma transicional es infrecuente y se asocia a un mal pronóstico debido a que su presencia indica diseminación metastática multiorgánica.

Palabras clave: Priapismo maligno. Cancer vesical.

\section{INTRODUCCIÓN}

Priapism is a condition in which the erection of the penis does not disappear with time, despite the absence of physical stimulation or sexual desire (1). There are two types of causes for this condition: Primary or idiopathic priapism and secondary priapism. The main etiology is iatrogenesis due to medical praxis; other causes are hematological diseases, such as sickle-cell anemia or leukemia, neurological disorders, infectious diseases or metabolic disorders. Another rare cause for priapism, which represents between $3 \%$ and $8 \%$ of all cases, is the involvement in neoplastic processes (2).

\section{CLINICAL CASE}

Our patient, with no relevant record, was diagnosed in 2006 with a transitional cell bladder neoplasia (pT3G3), which was treated at first with a transuretral resection. The extension study reveals hepatic metastases and retroperitoneal adenopathies (compatible with a stage T4N2M1) (Figure 1), and the patient is referred to our centre. He starts chemotherapy treatment with cycles of Carboplatin and Gemcitabine, and a partial response is observed. In March 2007, the patient presents an episode of hematuria which requires radiotherapy, followed by new cycles of chemotherapy. In December 2007, he presents a new episode of hematuria; an exploration of the bladder with anesthesia is performed, as a palliative attempt, revealing a bladder full of clots and a tumor mass that cannot be completely resected (Figure 2).
Afterwards, the patient presents an episode of paraphimosis, followed by symptoms of acute urinary retention, which required the installation of a permanent urethral catheter. Shortly after, he began a prolonged penile tumefaction (Figure 3).

Penile exploration shows painful corpus cavernosum induration. In that moment, DRE not impressed a suspicious prostate malignancy.

Laboratory blood parameters were normal, with values of prostate specific antigen $0.67 \mathrm{ng} / \mathrm{ml}$.

We perform a percutaneous biopsy of the corpus cavernosum and we attempt to drain it. The results of the pathological anatomy show a metastasis of carcinoma of transition cells (Figure 4). The therapeutic approach, given the characteristics of the patient, was palliative, through analgesic treatment and conservative measures. Currently, the patient is still being treated in our unit, with a progressive worsening of his general condition.

\section{DISCUSSION}

Metastatic priapism is a rare clinical condition. The main locations of the primary tumor are the bladder and the prostate $(3,4,6)$; Other locations and primary tumors described in the literature include: kidney, rectosigmoid junction, testicles, lungs, liver, stomach, lungs, mandibular chondrosarcoma, malignant melanoma, Burkitt's lymphoma, leukemoid reactions, paraneoplastic reactions and nasopharynx $(2,5)$. The most commonly affected part is the corpus cavernosum, followed by the glans penis and the corpus spongiosum (4). The malignant neoplastic lesion spreads towards the corpus cavernosum through direct infiltration, lymphatic or venous trans-

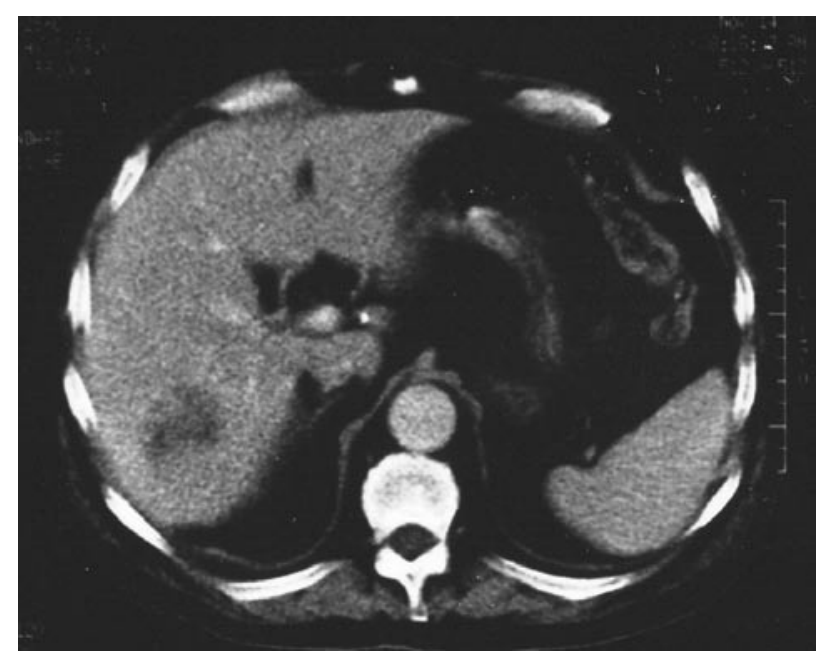

FIGURE 1. Liver Metastasis. 


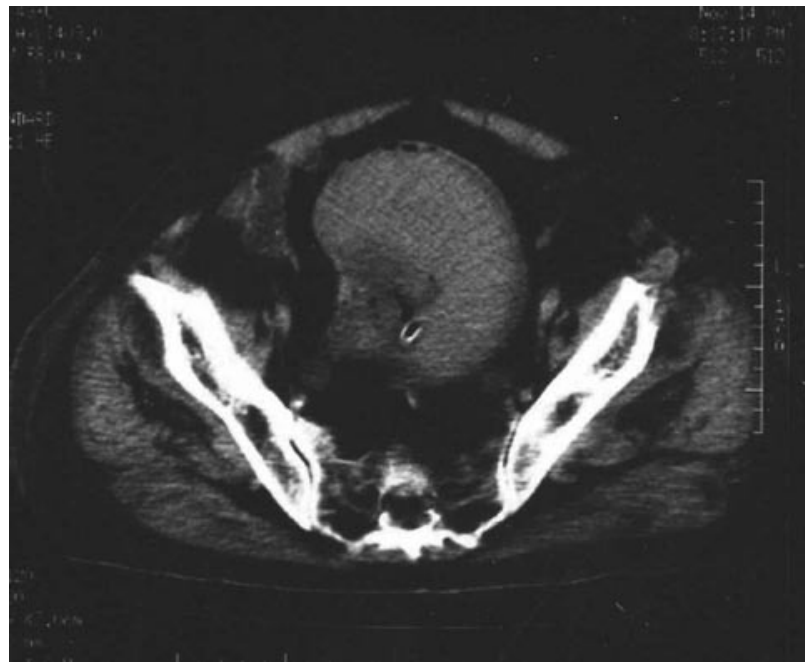

FIGURE 2. Extensive bladder neoplasia.

port or arterial embolism (1). Priapism appears as the result of an obstruction or a thrombosis of the corpus cavernosum, or of an irritation of the neuronal pathway due to the metastatic tumor. However, an arterial rupture caused by the invasion of a tumor can result in high-flow priapism (1).

This condition usually starts with a penile tumefaction, that is sometimes painful, dysuria, skin lesions secondary to tumor infiltration, paraphimosis, and even symptoms of hematuria and acute urinary retention secondary to the tumor infiltration into the urethra and the corpus spongiosum $(1,2,4,6)$.

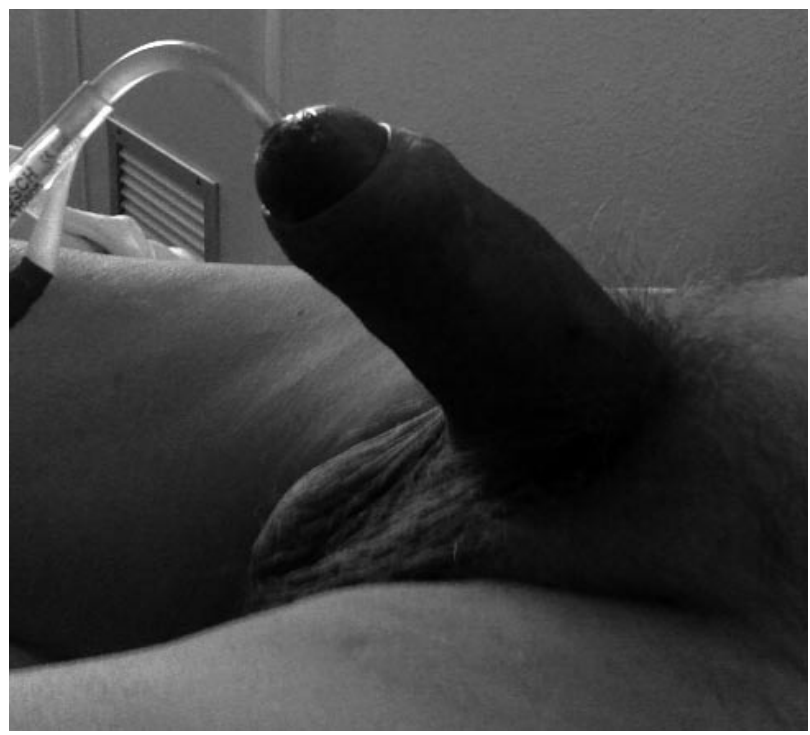

FIGURE 3. Priapism with malignant bladder catheterization.
An ultrasound of the penis is a sensitive method to reveal metastatic lesion. The echo-Doppler helps us distinguish between low-flow and high-flow priapism. The definitive diagnosis is confirmed by the biopsy of the corpus cavernosum $(1,2,4,6,7)$. The dissemination study is completed with a $C T$, a lung $x$-ray and a bone scan, because usually there is a synchronic metastatic involvement of other organs.

The differential diagnosis must include other disorders that present an induration of the corpus cavernosum, such as Peyronie's disease, thrombosis of the corpus cavernosum or thrombosis of the deep dorsal artery of the penis, idiopathic priapism, etc. $(4,5)$.

Penile metastasis indicate an advanced disease with a poor prognosis. The life expectancy is shorter than 1 year $(1,3,4)$. Metastatic lesions can be handled through local exeresis, partial or total penectomy, radiotherapy, chemotherapy or palliative therapy. The treatment is decided depending on the general condition of the patient, the size and the location of the lesion and the presence and type of priapism, as well as of the prognosis of the primary neoplasia. In patients with asymptomatic priapism with a short life expectancy, a conservative treatment can represent a reasonable choice $(1,6)$.

\section{CONCLUSION}

Metastatic priapism is a rare clinical condition. The diagnosis is confirmed with a biopsy of the corpus cavernosum. The poor prognosis in these patients, who die mostly during the first year, justifies the choice of a palliative treatment.

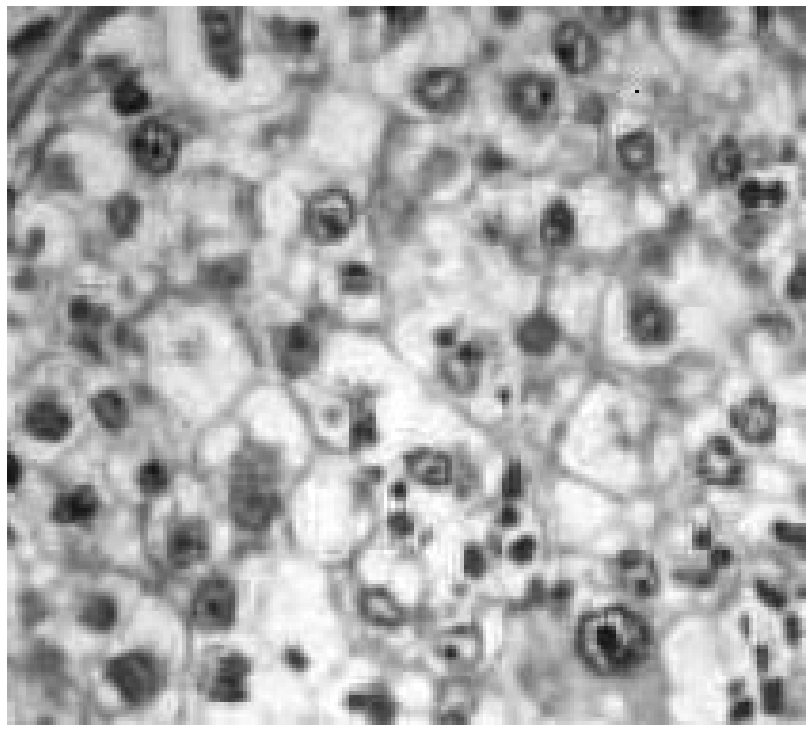

FIGURE 4. Image of cavernous metastasis. 


\section{REFERENCES AND RECOMENDED READINGS ( ${ }^{*}$ of special interest, ${ }^{* *}$ of outstanding interest)}

**1. Sezgin Guvel, Ferhat Kiling, Dilek Torun et al. Malignant priapism secondary to bladder cancer. Journal of Andrology, 2003; 24:499-500.

2. Rodríguez Alonso, Romero Picos, Suárez Pascual, et al. Priapismo secundario a reacción leucemoide paraneoplásica en paciente con cáncer de vejiga. Actas Urol Esp, 2004; 28:539-543.

3. Dubocq FM, Tefilli MV, Grignon DJ et al. High flow malignant priapism with isolate matastasis to the corpora cavernosa. Urology, 51, 324-326, 1998

*4. Robey E, Schellhammer P. Four cases of metastases to the penis and a review of the literature. J Urol, 1984; 132:992.

5. Cardoso G, Rodrigues R, Paiva Gadelha A et al. Penile matastasis of condrosarcoma of the jaw. Urology, 2003; 6:837.

*6. Trívez Boned, Aranda Lassa, Lozano Enguita y cols. Carcinoma transicional y priapismo metastático. Actas Urol Esp. 28(9):694-697, 2004

7. Kvarstein B. Bladder cancer complicated with priapism: a case report. Scand J Urol Nephrol Suppl, 1996; 179:155-156.

8. Morga Egea JP, Ferrero Doria R, Guzmán MartínezValls PL et al. Priapismo metastásico. Presentación de cuatro nuevos casos y revisión de la literatura. Arch. Esp. de Urol, 2000; 53:447-452. 